\title{
Effect of methionine load on homocysteine levels, lipid peroxidation and DNA damage in rats receiving ethanol
}

\author{
Alceu Afonso Jordao Júnior*, Fernanda Aparecida Domenici, Renata Cristina Lataro, \\ Guilherme Vannucchi Portari, Helio Vannucchi
}

\author{
Laboratory of Nutrition and Metabolism, \\ Faculty of Medicine of Ribeirão Preto, University of São Paulo
}

\begin{abstract}
Changes in the metabolism of methionine can cause hyperhomocysteinemia, inducing a triad of atherosclerosis, hypertension, and increased oxidative stress. The generation of free radicals and oxidative damage to DNA is important in the liver damage caused by ethanol. In this study, the effect of methionine overload associated or otherwise with acute administration of ethanol on homocysteine values, damage to DNA, lipoperoxidation and vitamin E was evaluated. Thirty rats were divided into 3 groups: Group Ethanol 24 hours (EG24), Group Methionine 24 hours (MG24), and Group Methionine and Ethanol 24 hours (MEG24). TBARS, vitamin E, GS and, homocysteine values were determined and the Comet assay was carried out. Increased GSH, vitamin E and homocysteine levels were observed for MEG24, and increased TBARS were observed in EG24. The Comet assay showed an increase in DNA damage in EG24 and DNA protection in MEG24. The administration of ethanol decreased antioxidant levels and increased TBARS, indicating the occurrence of oxidative stress with possible DNA damage. The combination of methionine and ethanol had a protective effect against the ethanol-induced damage, but increased the levels of homocysteine.
\end{abstract}

Uniterms: Methionine. Homocysteine. Free Radicals. Antioxidants. Ethanol/induced damage.

\begin{abstract}
Alterações no metabolismo da metionina podem ocasionar hiper-homocisteinemia, quadro indutivo de aterosclerose, hipertensão e aumento do estresse oxidativo. A geração de radicais livres e dano oxidativo ao DNA são importantes na injúria hepática provocada pelo etanol. Neste estudo avaliaram-se os efeitos da sobrecarga de metionina associada ou não à administração aguda de etanol sobre valores de homocisteína, dano ao DNA, lipoperoxidação e vitamina E. Foram utilizados 30 ratos Wistar distribuídos em 3 Grupos: Grupo Etanol 24 horas (GE24), Grupo Metionina 24 horas (GM24) e Grupo Metionina e Etanol 24 horas (GME24). Realizaram-se determinações hepáticas de SRATB, vitamina E, GSH, homocisteína e Teste do Cometa e determinações plasmáticas de GSH e homocisteína. Valores aumentados de GSH, vitamina E e homocisteína foram observados para o GME24, e de SRATB no GE24. O Teste do Cometa mostrou aumento do dano ao DNA no GE24 e proteção ao DNA no GME24. A administração de etanol diminuiu os níveis de antioxidantes e aumentou o de SRATB, indicando ocorrência de estresse oxidativo, podendo ocasionar dano ao DNA. A presença da metionina associada com o etanol agiu como protetora contra os danos do etanol, mas aumentou os níveis de homocisteína.
\end{abstract}

Unitermos: Metionina. Homocisteína. Radicais Livres. Antioxidantes. Etanol/danos.

\section{INTRODUCTION}

Methionine-rich diets can lead to hyperhomocysteinemia, a condition that induces the development of atherosclerosis and hypertension in rats and humans and

\footnotetext{
*Correspondence: Alceu Afonso Jordão Júnior. Curso de Nutrição e Metabolismo, Faculdade de Medicina de Ribeirão Preto - USP, Av. Bandeirantes 3900, 14049-900 - Ribeirão Preto - SP, Brasil. E-mail: alceu@fmrp.usp.br
}

that can also increase oxidative stress in vitro (Robin et al., 2004). Homocysteine (HCY) is a sulfurated amino acid originating from methionine metabolism that does not form proteins. HCY can be remethylated to methionine (transmethylation) or sulfo-conjugated with serine to form cysteine (transsulfuration) in a series of enzymatic reactions (Jung et al., 2003). The reactions in the methionine cycle also lead to the formation of the tripeptide glutathio- 
ne (GSH), with a strong involvement in the process of free radical formation and lipid peroxidation (Vannucchi et al., 1998; Jordão Jr et al., 1998).

Changes in methionine metabolism may result in high HCY levels (hyperhomocysteinemia), reflecting the deficiency of one or all of the three vitamins (folic acid, vitamin $\mathrm{B}_{6}$ or $\mathrm{B}_{12}$ ) involved in the process (El-Saleh et $a l ., 2004)$. The association of hyperhomocysteinemia in patients on hemodialysis may also lead to increased lipid peroxidation and changes in antioxidant levels, a condition that can be partially corrected by the administration of folate (Chiarello et al., 2003).

Experimental studies have suggested that HCY may have a pro-oxidant effect on the presence of metals such as iron and copper (Ventura et al., 2000). One of the classical ways to study the effects of hyperhomocysteinemia is to induce this condition by means of an oral methionine load test ( $100 \mathrm{mg} / \mathrm{kg}$ body weight), which can be applied to both animals and humans. This hyperhomocysteinemia mode due to oral methionine load leads to increased plasma oxidation and also to a reduction of antioxidants, whereas normal HCY levels have not demonstrated significant changes in antioxidant metabolism (Ventura et al., 2000).

Abnormal methionine metabolism occurs in animals subjected to ethanol intake and also in cirrhotic patients. The consequences of this metabolism may include a reduction of $S$-adenosylmethionine and of hepatic GSH, changes in methylation processes and a reduction of homocysteine catabolism resulting in hyperhomocysteinemia (Lee et al., 2004). An acute dose of ethanol ( $3 \mathrm{~g} / \mathrm{kg}$ body weight) induces significant changes in the metabolism of sulfurated amino acids in the liver, reducing the availability of cysteine for the synthesis of glutathione and also increasing the irreversible catabolism to taurine via hypotaurine (Jung et al., 2003).

The generation of free radicals is an important step in the liver damage provoked by ethanol. Acute or chronic ethanol administration can lead to increased lipid peroxidation via the exacerbated production of reactive oxygen species and/or a reduction of antioxidants such as vitamin E (Jordão Jr et al., 2004).

A study on lipid peroxidation caused by ethanol clearly showed that the maintenance of normal vitamin E levels is essential for antioxidant production. Vitamin E-deficient animals showed increased malondialdehyde (MDA) levels even without receiving ethanol. The same study demonstrated that the effects of ethanol are observed in a time-dependent manner, i.e., the results crucially depend on the time when the sample is collected (Jordão Jr et al., 2004).
After a single dose of ethanol ( $5 \mathrm{~g} / \mathrm{kg}$ body weight), urinary acetaldehyde excretion increases by about 5.8 times during a period of 6-12 hours, while formaldehyde increases only after 24 hours and lipid peroxidation measured by MDA concentration increases after 18 hours, thus representing an event secondary to the increase in acetaldehyde levels (Moser et al., 1993).

The above data show that there is a relationship between methionine overload and HCY levels, lipid peroxidation and oxidative DNA damage in rats and that ethanol intake can also influence the metabolism of sulfurated amino acids, correlations that would be interesting to study. Thus, the objective of the present study was to assess the effect of a single methionine overload on HCY levels, on the possible oxidative damage to DNA, on the rate of lipoperoxidation and on vitamin E levels after acute ethanol administration in rats.

\section{MATERIAL AND METHODS}

The experiment was conducted in the Animal Facilities of the Department of Internal Medicine, Faculty of Medicine of Ribeirão Preto, University of São Paulo (USP). Thirty newly weaned male Wistar rats weighing approximately $60 \mathrm{~g}$ provided by the Central Animal House of FMRP-USP were used. The animals were divided into 3 groups:

Twenty-four hour Ethanol Group $(n=10)$ : rats receiving ethanol and a normal diet and sacrificed 24 hours after the period of acute ethanol intake.

Twenty-four hour Methionine Group $(\mathrm{n}=10)$ : rats receiving ethanol and a normal diet and sacrificed 24 hours after methionine overload.

Twenty-four hour Methionine plus Ethanol Group $(n=10)$ : rats receiving ethanol and a normal diet and sacrificed 24 hours after the period of acute ethanol intake and methionine overload.

Diets were prepared according to AIN-93 recommendations and offered to the rats in the animal house for one week for adaptation. Both the diets and water were available ad libitum.

The animals were weighed at the time of sacrifice. The animals of the Ethanol and Methionine plus Ethanol groups received by gavage an ethanol solution at the concentration of $5 \mathrm{~g} / \mathrm{kg}$ body weight.

The animals of the Methionine and Methionine plus Ethanol groups received methionine by intraperitoneal injection at the concentration of $100 \mathrm{mg} / \mathrm{kg}$ body weight, diluted in water. At sacrifice the animals were anesthetized with ether and killed by exsanguination, with blood being removed by cardiac puncture (right ventricle) for 
plasma determination of HCY and GSH. The liver was then removed and weighed and immediately placed in liquid nitrogen $\left(-196^{\circ} \mathrm{C}\right)$ for later determination of thiobarbituric acid reactive substances (TBARS), GSH and $\alpha$-tocopherol.

Lipid peroxidation in the liver was measured by TBARS determination (Buege and Austi, 1978), GSH was determined by the method of Sedlack and Lindsay (1968), and hepatic vitamin E ( $\alpha$-tocopherol) was determined by HPLC (Arnaud et al., 1991). Protein determination, used to express the hepatic values of TBARS and GSH, was carried out by the method of Lowry et al. (1951).

Plasma and liver HCY was determined by HPLC with fluorimetric detection. This method is based on compound derivatization with $o$-ophthaldehyde in the presence of 2-mercaptoethanol, and separation through a $\mathrm{C} 18$ column with isocratic elution using $17 \%$ methanol and $0.04 \mathrm{M}$ sodium phosphate buffer, $\mathrm{pH}$ 7.0, 0.002 $\mathrm{Na}_{2}$ EDTA and fluorimetric detection at $340 \mathrm{~nm}$ excitation and $450 \mathrm{~nm}$ emission (Tcherkas, Denisenko, 2001).

Oxidative DNA damage to the hepatocytes was determined by the Comet test (single cell gel assay) according to Rojas and coworkers (1999). After staining with ethidium bromide, the slides were examined at 250 to $400 x$ magnification under a fluorescent microscope equipped with excitation filters and a barrier of $515-560 \mathrm{~nm}$ and $590 \mathrm{~nm}$, respectively. Approximately 50 cells selected at random were analyzed according to comet size and classified into five distinct classes, with the absence of damage being scored as 0 and maximum damage as 4 . Thus, the total score for 50 cells could range from 0 (no damage) to 200 (maximum damage for all cells).

Data are reported as means $\pm \mathrm{SD}$. Groups were compared by analysis of variance (ANOVA) and by the Tukey test, with the level of significance set at $p<0.05$.

\section{RESULTS AND DISCUSSION}

The data presented in Table I initially indicate that ethanol administration increases liver weight over a 24hour period, probably due to a greater deposition of hepatic fat, leading the animal to a state of alcoholic steatosis.

Ethanol causes steatosis by altering several steps in the hepatic processing of fatty acids, including their plasma uptake, their use as energy substrates, and their release as triglycerides (Maher, 2002).

Currently, it is of vital importance to study the role not only of ethanol but also of other nutritional components such as methionine and HCY in hepatic steatosis, in view of the great interest in the study of steatosis of non-alcoholic origin (Cortez-Pinto et al., 2006).

It should be pointed out that one of the most frequently used models of induction of steatosis and of non-alcoholic steatohepatitis is the offer of a choline- and methionine-free diet to the animals (Kirsch et al., 2003).

Table I also lists the values of antioxidant metabolism, with data on the hepatic and plasma concentration of reduced GSH, HCY and the hepatic concentrations of MDA and vitamin E.

The present results principally indicate a reduction of plasma and hepatic reduced GSH levels in animals receiving ethanol, but a preservation of these values in animals receiving methionine in combination with ethanol. The group receiving methionine alone showed increased GSH values, indicating that methionine administration can spare GSH in situations of oxidative stress or can even increase GSH in a natural manner, in the absence of acute stress such as that induced by ethanol administration.

These GSH data initially reflect the depletion of this antioxidant which is considered to play a key role in drug detoxification, being affected by ethanol. GSH levels decreased over a 24 hour period (Table I), showing that

TABLE I - Biochemical data for the animals that received methionine and/or ethanol and were sacrificed 24 hours later

\begin{tabular}{lccc}
\hline & MG24 & EG24 & MEG24 \\
\hline Liver weight $(\mathrm{g})$ & $4.68 \pm 0.35 \mathrm{a}$ & $5.41 \pm 0.53 \mathrm{~b}$ & $5.17 \pm 0.51 \mathrm{~b}$ \\
Hepatic GSH $(\mu \mathrm{mol} / \mathrm{g}$ protein $)$ & $45.17 \pm 6.175 \mathrm{a}$ & $27.65 \pm 7.07 \mathrm{~b}$ & $28.58 \pm 7.52 \mathrm{~b}$ \\
Plasma GSH $(\mu \mathrm{mol} / \mathrm{L})$ & $1.62 \pm 0.50 \mathrm{a}$ & $0.43 \pm 0.24 \mathrm{~b}$ & $0.57 \pm 0.23 \mathrm{~b}$ \\
Hepatic HCY $(\mu \mathrm{mol} / \mathrm{g}$ protein $)$ & $39.60 \pm 5.20 \mathrm{a}$ & $29.51 \pm 7.97 \mathrm{~b}$ & $32.51 \pm 5.79 \mathrm{ab}$ \\
Plasma HCY $(\mu \mathrm{mol} / \mathrm{L})$ & $42.53 \pm 11.73 \mathrm{a}$ & $25.91 \pm 4.72 \mathrm{~b}$ & $26.53 \pm 2.26 \mathrm{~b}$ \\
Hepatic MDA $(\mathrm{nmol} / \mathrm{mg}$ protein $)$ & $0.15 \pm 0.02 \mathrm{a}$ & $0.25 \pm 0.02 \mathrm{~b}$ & $0.18 \pm 0.02 \mathrm{a}$ \\
Hepatic vitamin E $(\mu \mathrm{g} / \mathrm{g}$ tissue $)$ & $18.55 \pm 2.92 \mathrm{a}$ & $14.11 \pm 1.85 \mathrm{~b}$ & $13.54 \pm 2.32 \mathrm{~b}$ \\
\hline
\end{tabular}

MG24 - 24-hour methionine group; EG24 - 24-hour ethanol group; MEG24 - 24-hour methionine plus ethanol group; GSH glutathione; HCY - homocysteine; Means followed by different letters on the same line differed significantly $(\mathrm{p}<0.05)$. 
during this period there is not yet complete GSH recovery in the presence of acutely administered ethanol.

GSH plays an important role in the antioxidant defense system, in the metabolism of various nutrients and in the regulation of cellular events including DNA damage, gene expression and apoptosis where its deficiency contributes to oxidative stress (Wu et al., 2004). However, these effects of GSH on the mechanisms of lipid and protein oxidation need to be better elucidated (Biswas et al., 2006).

As expected, a significant increase in HCY levels was demonstrated only in animals receiving methionine, while an intermediate value was observed in the group receiving methionine plus ethanol, and ethanol administered alone had no effect of HCY levels.

A recently published study described the influence of various factors such as ethanol intake and polymorphisms of the enzyme methylene tetrahydrofolate reductase (MTHFR) on total HCY values, indicating that many of these effects can be modulated by nutritional status in terms of folic acid (Chiuve et al., 2005). Folate deficiency may also be directly responsible for the increased activity of the enzyme glycine $n$-methyltransferase, which regulates the levels of $S$-adenosylmethionine and $S$-adenosylhomocysteine (Uthus et al., 2006).

Ethanol administration can result in DNA hypomethylation and in greater lipid deposition in the liver and also alters the hepatic metabolism of methionine, leading to changes in the $S$-adenosylmethionine-dependent transmethylation process (Schalinske et al., 2005).

The present results show that the administration of methionine in combination with ethanol was able to preserve several important parameters such as GSH levels.

On the other hand, lipoperoxidation indirectly measured by the TBARS test indicated that hepatic TBARS levels were higher only in the group receiving ethanol, with the addition of methionine to the acute ethanol dose preventing the elevation of this biochemical parameter of lipoperoxidation.

The levels of hepatic vitamin E, the main liposoluble antioxidant, were higher in the group receiving methionine only (Table I), being reduced in the groups that received ethanol or ethanol plus methionine.

The reduction of vitamin E levels probably demonstrates the utilization of this vitamin in the process of detoxification and recovery of the animal after ethanol consumption. We suggest that further studies prolonging the time in a similar experiment may determine whether vitamin $\mathrm{E}$ is recycled and recovered in the subsequent period. An experiment using different vitamin E levels (normal, deficient and supplemented) in the presence of acute ethanol intake, with the animals being sacrificed at different time points, clearly showed that vitamin $\mathrm{E}$ is reduced up to 8 hours after ethanol intake but that these hepatic levels are restored within a period of 24 hours, except in animals who already have vitamin E deficiency (Jordão Jr et al., 2004).

Table II presents the data regarding oxidative DNA damage determined by the Comet test. The data clearly demonstrate the increased DNA damage induced by acute ethanol administration and DNA protection when ethanol is administered together with methionine, a fact that may be explained by protection against the increase in lipid peroxidation in the ethanol plus methionine group. This shows the existence of a relation between TBARS levels and DNA damage, with consumption of hepatic antioxidants occurring in both groups receiving ethanol.

TABLE II - DNA damage (Comet test) in the animals that received methionine and/or ethanol and were sacrificed 24 hours later. Data are reported as mean \pm SD DNA damage (Comet test) for animals that received Methionine and/or Ethanol and were sacrificed 24 hours later

\begin{tabular}{lc}
\hline Groups & DNA Damage \\
\hline MG24 & $141.38 \pm 11.98^{\mathrm{a}}$ \\
EG24 & $172.63 \pm 18.94^{\mathrm{b}}$ \\
MEG24 & $144.75 \pm 8.60^{\mathrm{a}}$ \\
\hline
\end{tabular}

MG24 - 24-hour methionine group; EG24 - 24-hour ethanol group; MEG24-24-hour methionine plus ethanol group; Means followed by different letters differed significantly $(\mathrm{p}<0.05)$.

The DNA changes observed by the comet test are known to depend on the ethanol amount administered and also on the form of administration (chronic or acute), with higher ethanol doses leading to greater oxidative DNA damage (Lamarche et al., 2003).

Pretreatment with vitamin C $(400 \mathrm{mg} / \mathrm{kg} /$ day $)$ or vitamin $\mathrm{E}(100 \mathrm{mg} / \mathrm{kg} / \mathrm{day})$ for 5 days before acute ethanol administration $(5 \mathrm{~g} / \mathrm{kg})$ inhibits the generation of the hydroxyethyl radical by 30 and $50 \%$, respectively, and prevents oxidative DNA damage, which is high in groups receiving no antioxidants (Navasumrit et al., 2000).

The results demonstrate that acute ethanol administration reduces antioxidant levels (vitamin E and GSH) and increases TBARS levels, events that indicate the occurrence of oxidative stress in the liver of these animals possibly leading to oxidative DNA damage. Methionine administered in combination with ethanol prevented the increase in TBARS, probably with antioxidant (vitamin E and GSH) consumption and this lack of TBARS increase was reflected in the preservation of DNA from oxidative damage. 
Two distinct, although interlinked processes may be present, i.e., an unquestionable increase of oxidative damage in the presence of acute ethanol intake and the preservation of some of these parameters in the presence of also acute administration of methionine, with the consequent expected harmful occurrence of increased $\mathrm{HCY}$ levels.

\section{REFERENCES}

ARNAUD, J.; FORTIS, I.; BLACHIER, S.; KIA, D.; FAVIER, A. Simultaneous determination of retinol, alpha-tocopherol and beta-carotene in serum by isocratic high-performance liquid chromatography. J. Chromatogr, v.572, n.1/2, p.103116, 1991.

BISWAS, S.; CHIDA, A. S.; RAHMAN, I. Redox modifications of protein-thiols: emerging roles in cell signaling. Biochem. Pharmacol., v.71, n.5, p.551-564, 2006.

BUEEG, J. A.; AUST, S. D. Microsomal lipid peroxidation. Methods Enzymol., v.52, p.302-310, 1978.

CHIARELLO, P. G.; VANNUCCHI, M. T.; MOYSES NETO, M.; VANNUCCHI, H. Hyperhomocysteinemia and oxidative stress in hemodialysis: effects of supplementation with folic acid. Int. J. Vitam. Nutr. Res., v.73, n.6, p. 431438,2003

CHIUVE, S. E.; GIOVANNUCCI, E. L.; HANKINSON, S. E.; HUNTER, D. J.; STAMPFER, M. J.; WILLETT, W. C.; RIMM, E. B. Alcohol intake and methylenetetrahydrofolate reductase polymorphism modify the relation of folate intake to plasma homocysteine. Am. J. Clin. Nutr., v.82, n.1, p.155162,2005

CORTEZ-PINTO, H.; DE MOURA, M. C.; DAY, C. P. Nonalcoholic steatohepatitis: from cell biology to clinical practice. J. Hepatol., v.44, n.1, p.197-208, 2006.

EL-SALEH, S. C.; AL-SAGAIR, O. A.; AL-KHALAF, M. I. Thymoquinone and Nigella sativa oil protection against methionine-induced hyperhomocysteinemia in rats. Int. $J$. Cardiol., v.93, n.1, p.19-23, 2004.

JORDAO JR, A. A.; CHIARELLO, P. G.; ARANTES, M. R.; MEIRELLES, M. S.; VANNUCCHI, H. Effect of an acute dose of ethanol on lipid peroxidation in rats: action of vitamin E. Food Chem. Toxicol., v.42, n.3, p.459-464, 2004.
JORDÃO JR., A. A; CHIARELLO, P. G.; BERNARDES, M. M.; VANNUCCHI, H. Peroxidação lipídica e etanol: papel da glutationa reduzida e da vitamina E. Medicina, v.31, p.434-449, 1998.

JUNG, Y. S.; KWAK, H. E.; CHOI, K. H.; KIM, Y. C. Effect of acute ethanol administration on S-amino acid metabolism: increased utilization of cysteine for synthesis of taurine rather than glutathione. Adv. Exp. Med. Biol., v.526, p.245$52,2003$.

KIRSCH, R.; CLARKSON, V.; SHEPHARD, E. G.; MARAIS, D. A.; JAFFER, M. A.; WOODBURNE, V. E.; KIRSCH, R. E.; HALL PDE, L. Rodent nutritional model of nonalcoholic steatohepatitis: species, strain and sex difference studies. J. Gastroenterol. Hepatol., v.18, n.11, p.1272-1282, 2003.

LAMARCHE, F.; GONTHIER, B.; SIGNORINI, N.; EYSSERIC, H.; BARRET, L. Acute exposure of cultured neurones to ethanol results in reversible DNA single-strand breaks; whereas chronic exposure causes loss of cell viability. Alcohol Alcohol, v.38, n.6, p.550-8, 2003.LEE, T. D.; SADDA, M. R.; MENDLER, M. H.; BOTTIGLIERI, T.; KANEL, G.; MATO, J. M.; LU, S. C. Abnormal hepatic methionine and glutathione metabolism in patients with alcoholic hepatitis. Alcohol Clin. Exp. Res., v.28, n.1, p.173-181, 2004.

LOWRY, O. H.; ROSEBROUGH, N. J.; FARR, A. L.; RANDALL, R. J. Protein measurement with the Folin phenol reagent. J. Biol. Chem., v.193, n.1, p.265-275, 1951.

MAHER, J. J. Alcoholic steatosis and steatohepatitis. Semin. Gastrointest. Dis., v.13, n.1, p.31-9, 2002.

MOSER, J.; BAGCHI, D.; AKUBUE, P. I.; STOHS, S. J. Excretion of malondialdehyde, formaldehyde, acetaldehyde and acetone in the urine of rats following acute and chronic administration of ethanol. Alcohol Alcohol, v.28, n.3, p.287295, 1993.

NAVASUMRIT, P.; WARD, T. H.; DODD, N. J.; O'CONNOR, P. J. Ethanol-induced free radicals and hepatic DNA strand breaks are prevented in vivo by antioxidants: effects of acute and chronic ethanol exposure. Carcinogenesis, v.21, n.1, p.93-99, 2000. 
ROBIN, S.; COURDEROT-MASUYER, C.; NICOD, L.; JACQUESON, A.; RICHERT, L.; BERTHELOT, A. Opposite effect of methionine-supplemented diet, a model of hyperhomocysteinemia, on plasma and liver antioxidant status in normotensive and spontaneously hypertensive rats. J. Nutr. Biochem., v.15, n.2, p.80-89, 2004.

ROJAS, E.; LOPEZ, M. C.; VALVERDE, M. Single cell gel electrophoresis assay: methodology and applications. $J$. Chromatogr. B Biomed. Sci. Appl., v.722, n.1/2, p.225$254,1999$.

SCHALINSKE, K. L.; NIEMAN, K. M. Disruption of methyl group metabolism by ethanol. Nutr. Rev., v.63, n.11, p.387391, 2005.

SEDLAK, J.; LINDSAY, R. H. Estimation of total, proteinbound, and nonprotein sulfhydryl groups in tissue with Ellman's reagent. Anal. Biochem., v.25, n.1, p.192-205, 1968.

TCHERKAS, Y. V.; DENISENKO, A. D. Simultaneous determination of several amino acids, including homocysteine, cysteine and glutamic acid, in human plasma by isocratic reversed-phase high-performance liquid chromatography with fluorimetric detection. J. Chromatogr. $A$, v.913, n.1-2, p.309-313, 2001.
UTHUS, E. O.; ROSS, S. A.; DAVIS, C. D. Differential effects of dietary selenium ( $\mathrm{Se}$ ) and folate on methyl metabolism in liver and colon of rats. Biol. Trace Elem. Res., v.109, n.3, p.201-214, 2006.

VANNUCCHI, H.; MOREIRA, E. A. M.; CUNHA, D. F.; JUNQUEIRA-FRANCO, M. V. M.; BERNARDES, M. M.; JORDÃO JR., A.A. Papel dos nutrientes na peroxidação lipídica e no sistema de defesa antioxidante. Medicina, v.31, p.31-44, 1998.

VENTURA, P.; PANINI, R.; VERLATO, C.; SCARPETTA, G.; SALVIOLI, G. Peroxidation indices and total antioxidant capacity in plasma during hyperhomocysteinemia induced by methionine oral loading. Metabolism, v.49, n.2, p.225$228,2000$.

WU, G.; FANG, Y.Z.; YANG, S.; LUPTON, J. R.; TURNER, N. D. Glutathione metabolism and its implications for health. J. Nutr., v.134, n.3, p.489-492, 2004.

Received for publication on $13^{\text {th }}$ August 2008. Accepted for publication on $20^{\text {th }}$ January 2009. 